\title{
BRI and the Internationalization of China's Renminbi
}

\author{
Xinran Hou ${ }^{1,{ }^{*}, \dagger}$, Shenyan Huang ${ }^{2,{ }^{*}, \dagger}$, Mengyue Liu ${ }^{3,}{ }^{*},+$, Peiyang Zhang ${ }^{4,}{ }^{*}, \dagger$ \\ ${ }^{1}$ School of Arts and Sciences, University of Rochester, Rochester, NY 14627, USA \\ 2School of Social Science, University of California, Irvine, CA 92697, USA \\ ${ }^{3}$ School of Management, Shanghai University, Shanghai, 200444, China \\ ${ }^{4}$ Goodman School of Business, Brock University, St. Catharines, ON L2S3A1, Canada \\ *Corresponding author. Email: xhou7@u.rochester.edu \\ tThese authors contributed equally
}

\begin{abstract}
Ever since the proposition of Belt and Road Initiative, known as BRI, by President Xi of China in 2013, it has accelerated the internationalization of RMB in many different ways, involving financing, investment and so forth. This study affirms the feasibility of using BRI to encourage RMB's internationalization around the globe. The situations of related regions and Chinese corresponding endeavor have been discussed separately, for example, 17+1 cooperation achievement in transport sector in Europe, investments to Africa in large infrastructure, industrial, and communications projects, and taking advantage of Egypt's "zero tariff" in the Middle East. Afterwards, the analysis of central bank currency swaps and points out the benefits offered by RMB's internationalization for closing the infrastructure gap of BRI, and the BRI's providing better opportunity to further the internationalization of RMB. Finally, both opportunities and challenges for RMB's internationalization in related to $B R I$ are discussed. This paper reveals that the internationalization of RMB via $B R I$ is promising. Despite all kinds of challenges which are confronted by China, the country is given giant hope to handle well and convert those into opportunities, to encourage the use of RMB around the globe and make its contribution to world's economy.
\end{abstract}

Keywords: RMB Internationalization; Belt and Road Initiative (BRI); Liquidity, Bulk commodity.

\section{Introduction}

RMB internationalization improves China's ability to reform global monetary system, develop domestic financial system, expand cross-border RMB trade and strengthen the RMB exchange rate. Including RMB into SDR, establishing AIIB and BRI has accelerated the process of RMB internationalization. BRI enables the regionalization of the RMB, on the one hand, strengthen the influence of the RMB in the countries along the BRI and raise RMB's status as an international currency. The study describes the economic situation and industrial structure of BRI countries, including 2.1 Europe, 2.2 South Asian,2.3 Africa and 2.4 Mideast.

The study will address trade and investment projects along the BRI countries and use observational data of trade settlement, 3.1 RMB currency circulation, and 3.2 bulk commodity pricing to test the process of RMB internationalization. Chinese promotes RMB internationalization by first building swap lines with countries along the BRI to achieve a sufficient circulation of RMB currency abroad. Secondly, and most importantly, make RMB financial products an investment tool for major international financial institutions, including the central bank. Therefore, the scale of the financial market denominated in RMB has been continuously expanded. Thirdly, increases transactions in which RMB settlement accounts for a certain proportion of international trade.

This study will further study 4.1 the external and internal factors that will hinder the acceleration of RMB internationalization such as the potential conflicts between different political and financial systems, 4.2 the opportunity it brings to future includes more rapid domestic economic growth, multilateral trade and cooperation, and global development that meet the needs of everyone.

According to Yu et al., China's "Belt and Road" program has greatly increased commercial relations with its neighbors while also opening up new opportunities for RMB regionalization. Yu et al. evaluated the regionalization difficulties and gives some solutions for boosting regionalization 
based on the current condition of RMB circulation along "the Belt and Road." Yu et al. drew a conclusion that the significance of the RMB in pricing and settlement is becoming increasingly obvious in the execution and promotion of the "Belt and Road" plan. On the other hand, Yu et al. stressed that the adoption of this approach has provided ideal conditions for RMB regionalization. According to $\mathrm{Yu}$ et al., the RMB will play a full role in the future if China continues to develop trade relations with nations and regions along "The Belt and Road" route, as well as support ongoing reform of financial markets and regulatory institutions. Yu et al. believed that along this path, the RMB will really become a competitive reserve currency among the countries and area, attaining RMB regionalization and internationalization [1].

BRI is likely to have positive influences on the RMB systemic stability and rise the global position of RMB. Zhang investigated at the consequences of RMB internationalization on the global monetary system. The speed and manner with which Chinese authorities liberalize the capital account, the consistency and transparency of Chinese domestic monetary policy, and other domestic economic fundamentals such as banking regulation, financial stability, and fiscal policy, according to Zhang, are likely to determine the impact of the RMB on systemic stability [2]. As a consequence of a mix of security concerns and domestic political and economic motivations, Gjoza believed China has made aggressive measures to make the RMB a prominent worldwide currency. Gjoza explained that these efforts have paid off, as demonstrated by the RMB's expanding use in Southeast Asia, Central Asia, and portions of Europe for transactions and debt financing, as well as its inclusion in the IMF's SDR basket. The RMB, according to Gjoza, is still not a real international currency on par with the yen or the pound. Gjoza concluded that a truly international RMB, particularly one that becomes a potential dollar competitor, would be detrimental to U.S. interests in a variety of ways, including: allowing China to build an alternative global financial and economic network based on RMB that is independent of the dollar markets and the reach of the U.S. Treasury and increasing China's ability to influence third-party countries [3].

The influences of BRI on other countries and regions was also mentioned in Jin et al.'s article. The impact of renminbi (RMB) internationalization on economic integration between China and its partners, particularly Belt and Road nations, was examined in Jin et al.'s article. Between 2000 and 2016, Jin et al. gathered data on all bilateral swap agreements and empirically investigated the effect of bilateral swap agreements in bilateral trade flows between China and its partner countries. Jin et al. looked at the impacts of the gravity equation and discovered that swap agreements had a substantial beneficial impact on trade. The benefit is considerably larger for Belt and Road nations, according to Jin et al., which is statistically and economically significant. Jin et al. utilized a different measure of swap agreements and a different estimating approach. RMB swap agreements, according to Jin et al., are advantageous for economic integration between China and Belt and Road nations by promoting bilateral commerce [5].

BRI also includes some essential infrastructure construction in partners' countries. Bird, J., et al. analyzed the change in connectivity caused by BRI infrastructure improvements, added the effects of a package of measures to reduce border crossing times, and came to the following conclusions: With restricted supply response, the full gains are 36 percent larger than direct transportation cost savings created by building BRI infrastructure, which is associated with large increases in. Furthermore, because of the more elastic supply response, the overall advantages are expected to be substantially greater, roughly double the direct cost reductions [6].

The approaches of achieving RMB internationalization after implementing BRI are discussed in Li et al. and Chanthamith, B., et al.'s article. Li et al. introduced a fundamental concept of the internationalization process, emphasizing that a country's currency must follow the development route of "peripheralization-regionalization-globalization." In terms of the degree of globalization of the $\mathrm{RMB}, \mathrm{Li}$ et al. still considered today to be a transitional moment from peripheralization to regionalization. According to $\mathrm{Li}$ et al., the beneficial impact of BRI on RMB internationalization includes: 1) increasing the usage of foreign RMB and increasing China's influence on the global economy; and 2) facilitating the gradual opening up of China's whole financial sector and the 
realization of the RMB "going out" 3) Realize the overseas financing of RMB as the denominated currency and broaden the direct financing channels [8]. According to Chanthamith, B., et al., one critical step must be done to remove trade and investment limitations in order to lower trade costs and encourage economic development. Financial integration is one of the important goals of the BRI initiative, according to Chanthamith, B., et al., and it can be achieved by encouraging monetary policy coordination, internalization of the RMB for trade and investment, motivating financial cooperation, creating regional financial institutions, strengthening risk management cooperation, and encouraging regional mechanisms for managing financial risks [7].

The report of The People's Bank of China focused on the implementation of RMB internationalization in 2019, the development of the offshore RMB market, and policies and measures for further RMB internationalization development in the future. According to the report, RMB still showed a growth trend during the special period of COVID-19. In 2019, when monetary policies around the world were relaxed, RMB policy tended to be stable, and the interest rate and exchange rate did not fluctuate greatly, attracting more entities and capital into China's financial market. It is worth noting that in 2019, China's cross-border payments totaled 19.67 trillion yuan, up $24.1 \%$ year on year, with a net inflow of 36.6 billion yuan. The BRI has also strengthened the amount of crossborder RMB settlement. In 2019, cross-border RMB settlement between China and neighboring countries reached 3.6 trillion yuan, up 18.5 percent year on year. Foreign-invested enterprises and Hong Kong, Macao and Taiwan invested enterprises are increasingly inclined to use RMB for settlement, accounting for $88 \%$ and $89 \%$ respectively. The RMB ranks fifth among the currency composition of the International Monetary Fund member countries holding reserve assets, with a market share of $1.95 \%$. RMB ranked fifth among the major international payment currencies, accounting for $1.76 \%$. The RMB's ability as an international reserve currency is becoming more and more obvious. Overall, the internationalization of RMB is constantly improving in terms of crossborder payment, RMB clearing system, securities investment business and other aspects [10].

Huang and Liu et al. forecasted the potential problems that BRI faces. Huang dissected that the Belt and Road Initiative is China's most ambitious international economic initiative, seeking to boost economic growth across a large region comprising subregions in Asia, Europe, and Africa. Huang appraised that the Belt and Road Initiative is multifaceted while infrastructure development is important, encompassing policy dialogue, unrestricted trade, financial assistance, and people-topeople exchange. Huang highlighted that it certainly has the potential to transform the underdeveloped "Belt \& Road" region into a new vibrant economic pillar, as well as to contribute to economic policy thinking by incorporating successful emerging market economies' experiences. However, Huang's article manifested the initiative faces significant challenges, such as a lack of a centralized coordination mechanism, the potential clash of different political regimes and beliefs, and the financial viability of cross-border projects [4]. According to Liu et al., the combination of policy receptivity, currency utility, practical procedures, and growing expertise with the renminbi may increase currency adoption along the historic silk road. Liu et al. argued that Indonesia's signal of renminbi receptivity may make the country more appealing to Chinese investment, whether through policy or private enterprises. However, Liu et al. also highlighted that legislative and regulatory hurdle to the renminbi's short and medium-term usability as a commerce, investment, and reserve currency exist, as countries along the contemporary Silk Road are challenged by devaluation and their currency reserve policies [9].

In this article, the economic conditions and industrial structure of some typical areas involved in BRI are discussed. The areas selected includes Europe, South Asian, Africa, and Mideast. Furthermore, using the approach of data analysis and theoretical analysis, this article describes the situation of the liquidity of RMB, which reflects the improvement of RMB internationalization after implementing BRI. Meanwhile, the impacts of BRI on bulk commodity and RMB internationalization are covered. Lastly, this article provides the risks, challenges and potential opportunities that RMB internationalization may face under the background of BRI. 


\section{Economic Conditions and Industrial Structure of Bri Regions}

\subsection{Europe}

\subsubsection{General Background}

The BRI project has been helping to promote the internationalization of RMB. While operating this project, China needs to strengthen its cooperation with countries in Europe and increase their demand for a unified currency. As we have learned from the example of Euro Zone, closer cooperation usually brings more flows of capital, labor and so forth, which propels the acceleration of economic integration. In this way, a unified currency is likely to become a beneficial as well as an essential part.

\subsubsection{7+1 Cooperation}

In 2012, a cooperation framework was announced between China and 16 Central and Eastern European countries, which is also named 16+1 Cooperation. In 2019, the Cooperation became the $17+1$ Cooperation, as Greece announced its participation in that year. Just like numerous other projects, the 17+1 Cooperation was retrospectively labelled a part of the BRI.

\subsubsection{Chinese FDI in Europe}

As is widely acknowledged, Europe is one prime destination for China's Foreign Direct Investment. For instance, in 2015, Chinese Silk Road Fund partly financed the country's acquisition of Pirelli in Italy. Besides, China's Costco Shipping acquired 51 percent of Greece's Piraeus Port Authority in 2016. And European countries also contribute their endeavor, as member states of EU and European institutions have been getting involved in financing BRI projects in various forms since 2015. For example, among 57 founding members of the China-led Asian Infrastructure Investment Bank, the so-called AIIB, 13 members were from Europe, including Germany, France, the UK, and Italy which are known as G7 countries.

\subsubsection{Transport Sector}

Besides Chinese FDI in EU members mentioned above, the Belt and Road project has arrived in several EU members states through different tremendous projects in the sector of transportation. The Chongqing-Duisburg railway line which was established in 2016, and the new railway service between the Austrian capital of Vienna and Chinese Freight hub of Chengdu launched in 2018 are both successful examples of the transport sector.

\subsection{South Asia}

The BRI South Asian country includes India, Pakistan, Bangladesh, Afghanistan, Sri Lanka, Maldives, Nepal and Bhutan. These countries are generally at low- and middle-income levels, with relatively slow economic development and low level of intra-regional cooperation. Some countries are even affected by the border conflict. Their industrial structure is dominated by agriculture and industry. Some countries, such as Nepal, as a tourist country, have a high proportion of tertiary industry, but their structure is simple and vulnerable to external factors, resulting in poor economic stability.

By opening up trade roads, economic cooperation between countries can be realized and the development of surrounding areas can be promoted. The main cooperation is product exchanges. China can also take advantage of the labor force advantages of South Asian countries to open factories to promote employment. At the same time, China is providing assistance to South Asian countries in infrastructure, medical technology, education and counterterrorism, while deepening cultural exchanges.

Take Pakistan as an example. The China-Pakistan Economic Corridor (CPEC) has opened trade routes between China and the Middle East and Africa, boosting the development of the western region, while oil from the Middle East can be transported through pipelines in Pakistan. CPEC taps China's capital and capacity to establish 'sustainable economic growth mechanism. Infrastructure includes 
transportation projects such as seaports, railways and airports, natural gas pipelines, energy cooperation such as thermal wind power, water conservancy projects and crop research LABS. On March 23, 2018, the first education cooperation project of CHINA-Pakistan Economic Corridor (CPEC), Tianjin University of Technology in Punjab, officially opened.

\subsection{Africa}

There are 46 countries of the Belt and Road Initiative in Africa, and most of them are classified as low income or lower middle income. Most of these countries lack infrastructure construction, medical and educational facilities, while their economic development mainly depends on natural resources such as oil and metals.

China has a history of quick and successful economic growth, which offers an enticing model for African countries to emulate. It has made significant investments in big infrastructural, industrial, and communications projects, which are critical precondition for governments throughout Africa and, more significantly, provide local populations with quick delivery, wide awareness of development, and active governance. Since its involvement in the infrastructure sector began in the 1960s, China has established a major presence across the African continent. Trade between China and Africa has grown substantially, from $\$ 1$ billion in 1980 to $\$ 128$ billion in 2016 [11]. It has made a total of \$143 billion in loans to Africa since 2000, with half of that amount made in the preceding four years alone, making it Africa's largest bilateral creditor [11]. During the 2018 Forum for China-Africa Cooperation in Beijing, China pledged Africa $\$ 60$ billion in development funding until 2021 [11].

China has made significant progress in Africa as a result of the BRI. It has invested in 52 of Africa's 54 countries on a bilateral basis and is set to enter the 53rd, Sao Tome \& Principe. China's official statistics show that 49 of the 54 countries have already signed memorandums of cooperation. Geographically, 22 of the 49 countries (almost half) are located in West Africa, with the other half divided between East Africa (12), North Africa (9), and Southern Africa (6). A Memorandum of Understanding (MoU) on BRI partnership was also signed between the African Union and China. While Memorandums of Understanding are not legally binding, they do codify Chinese involvement in the country, which the local government acknowledges. This makes it easier for Chinese companies to invest in these countries. Memorandums of Understanding (MOUs) signed by both parties can pave the way for a legally enforceable agreement.

\subsection{Middle East}

Among the 72 BRI-participating economies, 14 countries from Middle East and North Africa are now holding 8 BRI main projects (Table 1). Egypt is one of the most influential powers in the Middle East and the fulcrum of the BRI in the Middle East, China-Egypt Suez Economic and Trade Cooperation Zone (SEZ) is an important platform for China and Egypt to deepen economic and trade cooperation. The project's construction was jointly funded by Tianjin TEDA Holdings and the ChinaAfrica Fund in 2008. In January 2016, the second phase of the cooperation zone project was jointly inaugurated by President Xi and President Sisi of Egypt, the zone was then expanded from a total area of 1.34 to 6 square kilometers.

Table 1. Main BRI Projects in Mideast

\begin{tabular}{|c|c|c|}
\hline Project & Country & Type \\
\hline Suez Canal Economic Zone & Egypt & SEZ \\
\hline Tehran-Mashhad Railway & Iran & Transport \\
\hline Haifa Port & Israel & Transport \\
\hline Duqm Port Commercial Terminal and Operational Zone & Oman & Transport \\
\hline Dammam Riyadh Freight Line & Saudi Arabia & Transport \\
\hline Chad-Cameroon \& Chad-Sudan Railway & Chad & Transport \\
\hline Khartoum-Port Sudan Railway & Sudan & Transport \\
\hline Kumport Terminal & Turkey & Transport \\
\hline
\end{tabular}


China-Egypt relationship is a model of China-Arab and China-Africa cooperation. "After more than 10 years of development of SEZ, it not only increases taxes and promotes employment, but it also adds more important value for the cooperation, which is reflected in the continuous improvement of the local industrial system." said Liu Aimin, chairman of the China-Africa TEDA Investment Co., Ltd.

As more Chinese companies are willing to invest in Egypt and expand cooperation with Egypt in the fields of infrastructure construction, production capacity, science and technology, in the current unstable world trade environment, Egypt's "zero tariff" advantage, which benefits many countries and regions, has also brought convenience to Chinese companies to invest and set up factories here.

\section{Cross Board Rmb Settlement}

\subsection{RMB Liquidity from 2015 to 2020}

In the past decade, Bank of China had signed currency swap agreements with 41 countries in the Belt Road Initiative, those countries include Singapore, Malaysia, Thailand, South Korea, accompanied by the rise of tourism; Vietnam, Russia, North Korea, Myanmar, and Laos for border trading; Hong Kong and Macau due to economic ties with the Mainland China (Table 2). Because of the difficulty of obtaining loans from international financial institutions such as the International Monetary Fund during the Asian financial crisis in 1997, that emerging market countries, East Asian countries have accumulated foreign exchange reserves in the past 10 years to enhance their ability to withstand the impact of the financial crisis. However, with the increase in the stock of foreign exchange reserves, the cost of accumulating foreign exchange reserves has also become higher and higher. The use of central bank currency swaps can provide foreign currency liquidity and reduce dependence on foreign exchange reserves.

Along with the development of RMB cross border trade settlement since 2008, the Executive Board of IMF include RMB into the currency basket of the SDR as a fifth currency with a weight of the RMB in the SDR basket of 10.92\% on November 30, 2015. (PBOC, 2016)

The demand of domestic and foreign institutions for using RMB in direct investment had been increasing. As shown in Figure 1, the amount of the RMB settlement in the Outward Direct Investment (ODI) transactions in 2015 reached 110.71 billion yuan, a year-on-year increase of 395\%; Foreign Direct Investment (FDI) transactions reached 3386.97 billion yuan, a year-on-year increase of $253 \%$ (Figure 1). The Bank for International Settlements reported that "the average daily circulation of RMB is approximately $\$ 285$ billion in 2019 , despite the impact of the global economic and financial crisis caused by the new covid-19 epidemic, China still maintained the same scale of RMB circulation in 2020." (PBOC, 2020). 
Table 2. Central Bank Swap Lines (January 31, 2020)

\begin{tabular}{|c|c|c|c|c|c|}
\hline Countries & $\begin{array}{l}\text { Date of } 1^{\text {st }} \\
\text { agreement }\end{array}$ & $\begin{array}{l}\text { Initial Authorized } \\
\text { Value (RMB bn) }\end{array}$ & Countries & $\begin{array}{l}\text { Date of } 1^{\text {st }} \\
\text { agreement }\end{array}$ & $\begin{array}{l}\text { Initial Authorized } \\
\text { Value (RMB bn) }\end{array}$ \\
\hline Hong Kong & 2009-Jan & 200 & Hungary & 2013-Sep & 10 \\
\hline Maalaysia & 2009-Feb & 80 & Albania & 2013-Sep & 2 \\
\hline Indonesia & 2009-Mar & 100 & Eurozone & 2013-Oct & 350 \\
\hline Argentina & 2009-Apr & 70 & Switzerland & 2014-Jul & 150 \\
\hline Korea & 2009-Apr & 180 & Sri Lanka & 2014-Sep & 10 \\
\hline Belarus & 2010-Mar & 20 & Russia & 2014-Oct & 150 \\
\hline Iceland & 2010-Jun & 3.5 & Qatar & 2014-Nov & 35 \\
\hline Singapore & 2010-Jul & 150 & Canada & 2014-Nov & 200 \\
\hline $\begin{array}{c}\text { New } \\
\text { Zealand }\end{array}$ & 2011-Apr & 25 & Suriname & 2015-Mar & 1 \\
\hline Uzbekistan & 2011-Apr & 0.7 & Armenia & 2015-Mar & 1 \\
\hline Mongolia & 2011-May & 5 & $\begin{array}{l}\text { South } \\
\text { Africa }\end{array}$ & 2015-Apr & 30 \\
\hline Kazakhstan & 2011-Jun & 7 & Chile & 2015-May & 22 \\
\hline Thailand & 2011-Dec & 70 & Tajikistan & 2015-Sep & 3 \\
\hline Pakistan & 2011-Dec & 10 & Georgia & 2015-Sep & n.a. \\
\hline UAE & 2012-Jan & 35 & Morocco & 2016-May & 10 \\
\hline Turkey & 2012-Feb & 12 & Serbia & 2016-June & 1.5 \\
\hline Australia & 2012-Mar & 200 & Egypt & 2016-Dec & 18 \\
\hline Ukraine & 2012-June & 15 & Nigeria & 2018-May & 15 \\
\hline Brazil & 2013-Mar & 190 & Japan & 2018-Oct & 200 \\
\hline \multirow[t]{2}{*}{ UK } & 2013-Jun & 350 & Macao & 2019-Dec & 30 \\
\hline & & & Laos & 2020-Jan & n.a. \\
\hline
\end{tabular}

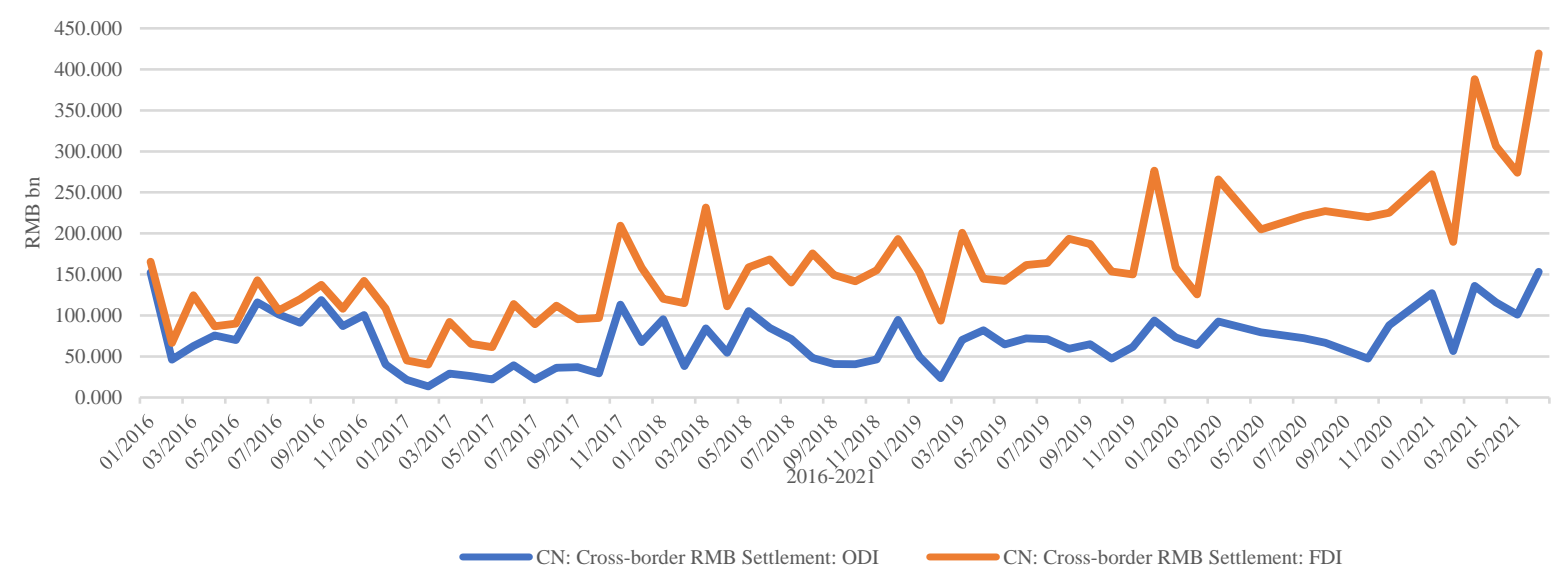

Figure 1. RMB-denominated ODI vs FDI

China is also increasing RMB circulation by developing digital assets, digital banking, digital currency, and sustainable finance by blockchain and crypto technology. Chinese payment system is increasingly integrated into the world in the past 5 years: Alipay and WeChat pay are accepted in more than 40 countries around the world.

In conclusion, RMB internationalization encourages more investment from both national and foreign countries for the BRI project to close the infrastructure gap. At the same time, the BRI provides a good opportunity to further the internationalization of the RMB. 


\subsection{Bulk commodity}

China is an important energy consumer in the world, but the pricing power of energy minerals such as oil and natural gas has long been dominated by developed countries in Europe and the United States.

In March 2018, Chinese crude oil futures denominated in RMB were listed for trading at the Shanghai International Energy Center, which promoted the process of valuing commodities in RMB. Countries such as Russia, Iran, Kazakhstan and other countries along the "Belt and Road" have begun to try to settle energy transactions in RMB to achieve "de-dollarization." This week, China will launch a new copper futures contract available to international traders in an effort to encourage yuan adoption and take some pricing power away from the established industry benchmark in London. Analysts believe that the inclusion of copper, the world's most-traded basic metal, to an expanding suite of international commodity futures will boost China's allure to the global trading community, even if yuan convertibility restrictions remain a barrier to widespread adoption. Such yuan-denominated products serve two strategic purposes: they provide another motivation for global market players to adopt the yuan while also strengthening China's pricing power in major commodity markets.

The RMB settlement of commodities can help promote the internationalization of the RMB.

As the renminbi is widely used in the settlement of bulk commodities, the renminbi may gradually become one of the international pricing currencies for bulk commodities, thereby further consolidating the pricing power of China's bulk commodities.

\section{Challenges and Opportunities}

\subsection{Challenges and risks}

Chinese capital market is not open today, and RMB is not fully convertible either. Thus, the financial products as well as relevant markets are very limited. As is widely acknowledged, international financial markets are heavily traded nowadays, no longer depending on the real economy anymore, and the sharing of derivatives trading is rising rapidly too.

Along with it emerges many more risks, for example, the difficulties of maintaining external balance, higher transaction risks. Moreover, attacks of speculators will be devastating as they play the triggers for currency crisis in the second generation of Currency Crisis Theory, as well as the catalyst of the crisis described in the first generation of Currency Crisis Theory. In addition, the government may be forced to drop its dependency of monetary policies in order to interfere with the foreign exchange market (Fixed or float exchange rate system) to stabilize RMB's value.

China has established trade partnerships with many countries along the route through the BRI and encouraged the use of RMB settlement in the Belt and Road at a more favourable exchange rate, the proportion of RMB settlement in international trade has continued to increase. At the same time, some countries with tense relations with the United States changed to use the RMB as their settlement currency. However, the U.S. dollar still occupies a dominant position in the international monetary system. As of March 2021, the U.S. dollar accounts for 56\% of the foreign exchange reserves of all countries in the world. The trading volume of the U.S. dollar in the foreign exchange market is as high as $88 \%$. As the main currency of the European Union, the euro also occupies an unshakable position. For China, the biggest challenge is how to make the country use RMB for settlement without preferential exchange rates or other favourable conditions. And for those countries that do not have much trade with China, if they are prompted to use RMB for settlement. Fundamentally, China should still strive to enhance its national strength and increase the stability of its currency in the future period, thereby enhancing its attractiveness to other countries. 


\subsection{Opportunities China has created}

\subsubsection{Issuing BRI relevant bonds}

In recent years, China has been kept trying on issuing specific bonds for infrastructure constructions of countries along the Road to encourage more cooperation with China, which is a significant tentative step for future generalization of the use of RMB. For instance, six kinds of bonds of BRI (including asset-backed securities) had been issued in 2019, and the money raised were used for Laos's cement project. The bonds are rated AAA and raised 6.7 billion Yuan by the end of that year.

\subsubsection{Establish offshore RMB markets}

By establishing offshore and onshore RMB markets, making them mature, and highly flowing, China aims to offer an appealing platform for RMB circulation which will attract foreign investors to choose RMB as investment tools and RMB holders to keeping holding it. The construction of the offshore RMB market used to rely on mature international financial centers such as Hong Kong (Figure 3). "Dim sum bond" is a slang term for one representative type of bonds denominated in Chinese renminbi and issued in Hong Kong. This kind of bonds are attractive to foreign investors who desire exposure to renminbi-denominated assets. Also, the expansive growth of the dim sum bond market in the last five years has peaked investor interest and inspired companies to seek out investing opportunities that negate China's capital controls which is very consequential.

Besides, several big steps have been made in 2020. For instance, in January, SAFE introduced several measures regarding FX hedging for offshore investors. In May, the PBOC and SAFE introduced another measure that simplified the capital requirements of offshore institutional investors and RMB QFII to invest in onshore securities and futures and removed the quota limits for QFII and RQFII as shown. These measures help to meet demands from international investors and promote China capital market reform, enabling it more mature.

Nowadays, with the advancement of the BRI, the scale of RMB settlement and denomination in cross-border trade, investment, and other activities is expected to generate needs for financing and investing in RMB financial assets such as deposits and bonds. It is of practical necessity to further develop the offshore market and enrich RMB financial products. Also, the offshore market can provide financial support for the BRI. As trade and investment activities along the Belt and Road are facing greater political, operational and environmental risks, the offshore market can provide special financing and risk management services for the BRI. For example, Horgos Border China-Kiaz International Collaborating Centre has been built as the offshore RMB market, providing places for transactions of offshore RMB.

Apart from that, some of the mentioned opening policies of financial markets have been tilted towards Belt and Road countries and regions, such as increasing the scope and quota of the RQFII program in these countries and strengthening market connectivity with international financial centers such as Qatar and Dubai, in order to stimulates the use of RMB in these countries and expedite the internationalization of RMB.

In a word, from what have been discussed above, we can predict that these policies along the Belt and Road will be continually pushed forward with gradually relaxing restrictions on overseas investors, strengthening connectivity between Chinese and overseas capital markets, and enriching the variety of RMB-denominated financial assets and essentially, encouraging the wider use of RMB.

\section{Conclusion}

This paper studies the relationship and influence between the Belt and Road initiative and RMB internationalization. This article introduced the specific content of the Belt and Road. Next, the economic development and industrial structure of this region are analysed by regional characteristic and also lists the cooperation with China in theses region by far. The third part analyses the current status of RMB internationalization. Through various data and figures, this paper evaluates the changes 
of RMB circulation degree since the beginning of the Belt and Road policy in 2013 and explains how the Belt and Road initiative promotes the internationalization of RMB based on related events. The last section deals with opportunities and challenges. According to the results, the Belt and Road initiative plays a huge role in promoting the internationalization of RMB, and its circulation and stability are constantly improved. More and more countries along the Belt and Road are choosing to use the yuan for settlement. Through research, we find that the circulation of RMB in other countries is still low, especially in some countries that do not have close trade relationships with China and some bulk commodities are not denominated in RMB. In the future, China should further strengthen the stability of the RMB and use more competitive means to increase the circulation of the RMB in the international market, rather than preferential interest rates, which is not a long-term solution.

\section{References}

[1] Yu, D., et al. (2020). The Challenge and Strategy Analysis of RMB Regionalization Against the Background of "the Belt and Road". Advances in Economics, Business and Management Research, volume 150.

[2] Gjoza, E. (2018). RMB Internationalization Implications for U.S. Economic Hegemony. Policy Analysis Exercise.

[3] Zhang, M. (2015). Internationalization of the Renminbi Developments, Problems and Influences. New Thinking and the New G20 Series paper No. 2, March 2015

[4] Huang, Y. (2016). Understanding China's Belt \& Road Initiative: Motivation, framework and assessment. China Economic Review Volume 40, September 2016, Pages 314 - 321.

[5] Jin, Y, et al. (2017). The Effect of RMB Internationalization on Belt and Road Initiative: Evidence from Bilateral Swap Agreements. Emerging Markets Finance and Trade, 53:12, 2845-2857, DOI: 10.1080/1540496X.2017.1382346.

[6] Bird, J., et al. (2019). The Belt and Road Initiative: Reshaping Economic Geography in Central Asia?. University of Oxford. The World Bank, April 2019.

[7] Chanthamith, B., et al. (2020). Belt and Road Initiative (BRI) of China: Connecting the World for Sustainable Economic Development. DOI: 10.4236/jss.2020.81009, PP. 109 - 120.

[8] Li, Y. (2019). The Impact of the Belt and Road Initiative on RMB Internationalization and Development Strategies for Mutual Benefit. Advances in Economics, Business and Management Research, volume 146

[9] Liu, S., et al. (2017). A Snapshot of Renminbi Internationalization Trends Under One Belt One Road Initiative. EMPEA Legal \& Regulatory Bulletin, Summer 2017.

[10] The People's Bank of China (2020). 2020 annual RMB international report. https://www.caixinglobal.com/upload/PBOC-2020-RMB-International-Report.pdf

[11] Lokanathan, V. (2020). China's belt and road initiative: Implications in Africa, ORF Issue Brief, Issue No.395. 